occurred in all cases. Injections of botulinum toxin A might, therefore, be extended to the treatment of other groups of muscles affected by spasmodic dystonia.

We thank Professor W I McDonald, Professor C D Marsden, and Professor A C Bird for referring patients and Miss Karen Betts for secretarial help.

\section{References}

1 Jan Kovic J, Havins WE, Wilkins RB. Blinking and blepharospasm: mechanisms, diagnosis, management. $\mathcal{J} A M A$ 1982;248:3160-4.

Ophthalmol Soc 1956;54:

453-519.
Marsden CD. Blepharospasm-oromandibular dystonia syndrome (Brueghel's syndrome). F Neurol Neurosurg Psychiatry 1976;39:1204-9.

Jan Kovic J, Ford J. Blepharospasm of orofacial-cervical dystonia: clinical and Casey DE Pharmacology of blepharospasm-oromandibular dystonia syndrome. Neurology 1980;30:690-5.

Jan Kovic J, Patel SC. Blepharospasm associated with brain stem lesions. Neurology $1983 ; 33: 1237-40$.

7 Skarf B, Sharp JA. Choline for blepharospasm. N Engl f Med 1981;305:957-8.
8 Bird AC, MacDonald WI. Essential blepharospasm. Trans Ophthalmol Soc UK 975;95:250-3.

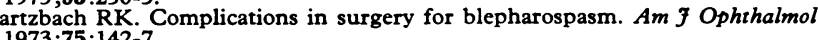
Cord CD, Coles

CW Shore JW, Spector R, Putman JR. Treatment of essential blepharospasm. Arch Ophthalmol 1984;102:266-73.

11 Gillum WN, Anderson RL. Blepharospasm surgery: an anatomical approach. Arch Ophthalmol 1981;99:1056-62.

12 Duchen LW, Strich SJ. Changes in the pattern of motor innervation of skeletal muscle in the mouse after local injection of Clostridium botulinum toxin. Physiol (Lond) 1967;189:2-4

13 Boroff DA, del Castillo J, Evoy WH, Steinherdt RA. Observations on the action of type A botulinum toxin on frog neuromuscular junctions. I Physiol (Lond) (974;240:227-53.

4 Guyton AC, MacDonald MA. Physiology of botulinum toxin. Archives of Neurology and Psychiatry 1947;57:578-92. toxin in the motor end plates of slow snd fast skeletal muscle fibres of the mouse. $\exists$ Neurol Sci 1971;14:47-60.

16 Duchen LW. Changes in the electron microscopic structure of slow and fast skeletal muscle fibres of the mouse after the local injection of botulinum toxin. f Neurol Sci 1971;14:60-74.

17 Scott AB. Botulinum toxin injection into extraocular muscles as an alternative to strabismus surgery Ophthalmology 1980;87:1044-7. ruch BR, Felt DP, Woino TH, Musch DC. Treatment of blepharospasm with
botulinum toxin. Arch Ophthalmol 1984;102:1464-8.

19 Tonge DA. Chromic effects of botulinum toxin on neuromuscular transmission and sensitivity to acetylcholine in slow and fast skeletal muscle of the mouse. f Physiol (Lond) 1974;241:127-39.

(Accepted 25 March 1985)

\title{
Relation between consumption of alcohol and fatty acids esterifying serum cholesterol in healthy men
}

\author{
JEAN-MICHEL WARNET, FRANÇOIS CAMBIEN, VIVIANE VERNIER, MARTINE PECORARO, \\ CLAUDIE FLAMENT, PIERRE DUCIMETIERE, ALAIN JACQUESON, \\ JACQUES-LUCIEN RICHARD， JEAN-ROGER CLAUDE
}

\begin{abstract}
The relation between consumption of alcohol (established by interview), two of its typical markers ( $\gamma$-glutamyltransferase activity and mean corpuscular volume), and the composition of fatty acids in plasma cholesterol esters was investigated in an epidemiological study of 1467 actively employed men aged 35-45. In this group of subjects mean consumption of alcohol was 34.6 (SD 25.2) g/day. Palmitoleic acid and oleic acid were positively correlated with consumption of alcohol, $\gamma$ glutamyltransferase activity, and mean corpuscular volume, while linoleic acid was negatively correlated with these variables. When these three fatty acids, $\gamma$-glutamyltransferase activity, mean corpuscular volume, and the fat content of the diet were introduced into a multivariate regression analysis, with consumption of alcohol as the dependent variable, only palmitoleic
\end{abstract}

Groupe d'Etude sur l'Epidémiologie de l'Athérosclérose, 75017 Paris, France

JEAN-MICHEL WARNET, PHD, professor

FRANCOIS CAMBIEN, MD

MARTINE PECORARO, PHD

PIERRE DUCIMETIERE, PHD

ALAIN JACQUESON, PHD

JACQUES-LUCIEN RICHARD, MD

JEAN-ROGER CLAUDE, PHD

Laboratoire de la Société Astra-Calvé, 92601 Asnières

VIVIANE VERNIER, technician

Unité 1 de l'Institut National de la Santé et de la Recherche Médicale, 75877 Paris Cedex 18

CLAUDIE FLAMENT, technician

Correspondence to: Professor Jean-Michel Warnet, Laboratoire de Recherches sur les Maladies Cardio-Vasculaires de la Direction des Affaires Sanitaires et Sociales de Paris, 88 Rue de la Jonquière, 75017 Paris, France. acid, $\gamma$-glutamyltransferase activity, mean corpuscular volume, and the monounsaturated fat content of the diet remained significant.

Palmitoleic acid seems to be an independent correlate of consumption of alcohol and could be useful in epidemiological and clinical studies as a variable of consumption.

\section{Introduction}

Studies in both animals ${ }^{1-3}$ and $\operatorname{man}^{4-7}$ have shown that consumption of alcohol, either acute or chronic, strongly modifies the pattern of fatty acids in the liver and serum lipids. In particular, a decrease in the proportion of hepatic and serum linoleic acid has been reported repeatedly in alcoholics. ${ }^{4-7}$ No epidemiological data have been available concerning this relation despite its possible importance in the association between coronary heart disease and the intake of alcohol and linoleic acid, which has been reported in some epidemiological and clinical studies. ${ }^{8-11}$

This paper reports the association observed between consumption of alcohol, two of its biological markers ( $\gamma$-glutamyltransferase activity and mean corpuscular volume), and the composition of fatty acids in plasma cholesterol esters in a group of apparently healthy men at baseline of the Paris prospective study II.

\section{Subjects and methods}

The reported results concern the cross sectional data obtained at entry into the Paris prospective study II from a subgroup of 1467 men aged 35-45. This study on cardiovascular risk factors began in 1982 , but follow up data were not yet available. The subjects of this study are male employees of a large public organisation in Paris, who undergo regular medical examinations. Each subject answered 
a series of questionnaires, including one on consumption of alcohol, and a 24 hour dietary recall. A sample of fasting blood was obtained and an extensive set of biological investigations performed, including measurements of $\gamma$-glutamyltransferase activity and mean corpuscular volume, and the determination of the composition of the fatty acids of plasma cholesterol esters.

The interviewer recorded thoroughly the types and quantities of food and alcohol consumed during the preceding 24 hours. The nutrients of the food consumed were estimated by a dietitian. ${ }^{12}$ The present analysis was concerned with the consumption of saturated, monounsaturated, and polyunsaturated fats. If during the past 24 hours consumption of alcohol was unusual more details were required concerning usual consumption and a special questionnaire was completed. This study was of usual consumption of alcohol, expressed in $\mathrm{g} /$ day.

Kinetic $\gamma$-glutamyltransferase (Enzyme Commission 2.3.2.2) activity was determined at $37^{\circ} \mathrm{C}$ and $410 \mathrm{~nm}$ with a reaction rate enzyme analyser using the method of Persijn and Van Der Slik ${ }^{13}$ with L- $\gamma$-glutamyl-3-carboxy-4-nitroanilide as substrate. Mean corpuscular volume was measured with a semiautomatic blood cell multiple counter.

Total serum lipids were extracted by the method of Folch et all4 and fractionated by thin layer chromatography on $0.2 \mathrm{~mm}$ silica gel plates (E Merck, Darmstadt, Germany) in $n$-hexane, ethyl ether, and acetic acid $(80: 20: 1 \cdot 5, \mathrm{vol} / \mathrm{vol})$. Bands were made visible by spraying the plate with $4^{\prime}-5^{\prime}$-dibromofluorescein in alcohol $(0 \cdot 10 \mathrm{~g} / \mathrm{l})$ and examined under ultraviolet light. The cholesterol ester fraction was scraped off and treated according to the procedure of Tuckey and Stevenson, ${ }^{15}$ slightly modified for saponification $\left(20 \mathrm{~min}\right.$ at $\left.60^{\circ} \mathrm{C}\right)$ and methylation $\left(60 \mathrm{~min}\right.$ at $\left.45^{\circ} \mathrm{C}\right)$. Methyl esters were extracted by $n$-hexane and separated with a glass capillary column $(45 \mathrm{~m} \times 0.25 \mathrm{~mm}$ inside diameter) coated with $20 \mathrm{M}$ Carbowax in a gas chromatograph (Girdel model 300) fitted with a hydrogen flame ionisation detector. The temperature was programmed for $200-220^{\circ} \mathrm{C}$, and all peaks corresponding to fatty acids from $\mathrm{C} 12: 0$ to $\mathrm{C} 22: 6$ were measured with a model Enica 10 Delsi integrator.

The results are expressed as means (SD). Standard methods were used to compute and test correlations and multiple regression coefficients.

\section{Results}

The mean daily consumption of alcohol was $34 \cdot 6(25 \cdot 2) \mathrm{g}$. The mean corpuscular volume was $91.1(4.5) \mathrm{fl}$, and the mean $\gamma$-glutamyltransferase activity was $42 \cdot 4(52 \cdot 1) \mathrm{U} / \mathrm{l}$. The mean intake of polyunsaturated, monounsaturated, and saturated fats was $0.65(0.41)$, $1.73(0.61)$, and $1.80(0.59) \mathrm{kJ}(155(99), 415(146)$, and 421 (140) calories), respectively. The ratio of polyunsaturated to saturated fats was $0.41(0 \cdot 32)$.

Thirteen fatty acids were identified by the analytical method used: the most important were palmitic (16:0), palmitoleic (16:1), stearic (18:0), oleic (18:1), linoleic (18:2), and arachidonic (20:4) acids, and their mean proportions were $13.0(2 \cdot 1) \%, 4 \cdot 1(1 \cdot 8) \%, 1 \cdot 5(0 \cdot 8) \%$, $19.9(3.3) \%, 47.5(5.6) \%$, and $6.8(1.7) \%$, respectively.

Palmitoleic, oleic, and linoleic acids were the only fatty acids of plasma cholesterol esters associated with consumption of alcohol and its biological markers; consequently, the other fatty acids were not considered further in the analysis. Table I shows that consumption of alcohol, $\gamma$-glutamyltransferase activity, and mean corpuscular volume were positively associated with palmitoleic and oleic acids and negatively associated with linoleic acid; the strongest association was with palmitoleic acid. Furthermore, consumption of polyunsaturated fats was negatively correlated with palmitoleic and oleic acids and positively correlated with linoleic acid as expected. To illustrate these relations further table II shows the mean values of the different variables in five classes of consumption of alcohol.

To clarify these multiple relations a stepwise regression analysis was performed with consumption of alcohol as the dependent variable and $\gamma$-glutamyltransferase activity, mean corpuscular volume, palmitoleic acid, oleic acid, linoleic acid, and the fat content of the diet as independent variables. Table III shows the results: only palmitoleic acid, $\gamma$-glutamyltransferase activity, mean corpuscular volume, and the intake of monounsaturated fats remained significant.

TABLE II-Mean values of relevant serum fatty acids of cholesterol esters, $\gamma$-glutamyltransferase activity, mean corpuscular volume, and dietary fats in relation to consumption of alcohol

\begin{tabular}{|c|c|c|c|c|c|}
\hline & \multicolumn{5}{|c|}{ Alcohol (g/day) } \\
\hline & $\begin{array}{c}0 \\
(n=56)\end{array}$ & $\begin{aligned} & <20 \\
(\mathrm{n} & =420)\end{aligned}$ & $\begin{array}{c}20-39 \\
(n=407)\end{array}$ & $\begin{array}{c}40-59 \\
(n=365)\end{array}$ & $\begin{array}{c}\geqslant 60 \\
(n=219)\end{array}$ \\
\hline $\begin{array}{l}\text { Palmitoleic acid (\%) } \\
\text { Oleic acid }(\%) \\
\text { Linoleic acid }(\%) \\
\gamma \text {-glutamyltransferase }\end{array}$ & $\begin{array}{r}3 \cdot 3 \\
18 \cdot 6 \\
50 \cdot 0\end{array}$ & $\begin{array}{r}3.4 \\
19.1 \\
49.5\end{array}$ & $\begin{array}{r}4 \cdot 0 \\
19 \cdot 8 \\
47 \cdot 3\end{array}$ & $\begin{array}{r}4 \cdot 5 \\
20 \cdot 3 \\
46 \cdot 6\end{array}$ & $\begin{array}{r}5 \cdot 4 \S \\
21 \cdot 3 \S \\
44 \cdot 9 \S\end{array}$ \\
\hline $\begin{array}{l}\text { activity (U/I) } \\
\text { Mean corpuscular volume }\end{array}$ & $21 \cdot 3$ & $30 \cdot 0$ & $38 \cdot 5$ & $46 \cdot 7$ & $72 \cdot 0 \S$ \\
\hline $\begin{array}{l}\text { (f) } \\
\text { Polyunsaturated fats }\end{array}$ & $88 \cdot 5$ & $89 \cdot 7$ & 90.6 & $92 \cdot 3$ & $93.3 \S$ \\
\hline $\begin{array}{l}\text { (kJ/day) } \\
\text { Monounsaturated fats }\end{array}$ & 0.54 & 0.68 & 0.63 & 0.68 & $0.61^{*}$ \\
\hline $\begin{array}{l}\text { (kJ/day) } \\
\text { Saturated fats (kJ/day) }\end{array}$ & $\begin{array}{l}1 \cdot 40 \\
1.43\end{array}$ & $\begin{array}{l}1 \cdot 68 \\
1 \cdot 73\end{array}$ & $\begin{array}{l}1 \cdot 75 \\
1 \cdot 78\end{array}$ & $\begin{array}{l}1.81 \\
1.81\end{array}$ & $\begin{array}{l}1 \cdot 79 \ddagger \\
1 \cdot 77 \dagger\end{array}$ \\
\hline
\end{tabular}

*NS, $+\mathrm{p}<0.001, \ddagger \mathrm{p}<0.00001, \S \mathrm{p}<0.0000001$.

Conversion: SI to traditional units-Energy: $1 \mathrm{~kJ} \approx 0.24 \mathrm{kcal}$

TABLE III-Multiple stepwise regression analysis of consumption of alcohol with relevant serum fatty acids of cholesterol esters, $\gamma$-glutamyltransferase activity, mean corpuscular volume, and dietary fats*

\begin{tabular}{lccc}
\hline \multicolumn{1}{c}{ Independent variable } & $\begin{array}{c}\text { Regression } \\
\text { coefficient }(\mathrm{SD})\end{array}$ & $\boldsymbol{t}$ Value & $\mathrm{p}$ Value \\
\hline Palmitoleic acid & $3 \cdot 08(0 \cdot 51)$ & $6 \cdot 0$ & $<10^{-8}$ \\
Log Y-glutamyltransferase activity $\dagger$ & $14 \cdot 7(2 \cdot 2)$ & $6 \cdot 6$ & $<10^{-8}$ \\
Mean corpuscular volume & $0 \cdot 77(0 \cdot 14)$ & $5 \cdot 2$ & $<10^{-6}$ \\
Monounsaturated fats & $0.018(0.004)$ & $4 \cdot 2$ & $<10^{-4}$ \\
\hline
\end{tabular}

${ }^{*} R^{2}=0.216$ when all independent variables are entered. Palmitoleic acid was first

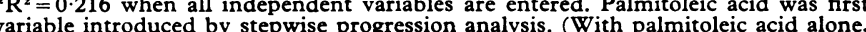
$\mathbf{R}^{2}=0 \cdot 161$.)

+Logarithmic transformation was applied to normalise distribution.

\section{Discussion}

In this group of subjects the mean consumption of alcohol was high but comparable with that observed in other French studies in similar age groups. ${ }^{16}$ Mainly wine was consumed (roughly $85 \%$ of total), which is generally served with each meal. These characteristics differ from those of other developed countries, where consumption of alcohol is lower and more episodic and different drinks are consumed. As table II shows, the intake of alcohol varied greatly, and large groups with different consumptions could be compared. The information concerning alcoholic and dietary consumptions was fairly general, which may reduce the value of the relation observed. The distribution of $\gamma$-glutamyltransferase activity and its relation with consumption of alcohol agree with those observed in other studies. ${ }^{13} 16$ The fatty acids of plasma cholesterol esters

TABLE I-Correlation coefficients between consumption of alcohol, $\gamma$-glutamyltransferase activity, mean curpuscular volume, relevant serum fatty acids of cholesterol esters, and dietary fats

\begin{tabular}{|c|c|c|c|c|c|c|c|c|}
\hline & \multirow{2}{*}{$\underset{\substack{\boldsymbol{L} \text {-glutamyltransferase } \\
\text { activity* }}}{\log }$} & \multirow{2}{*}{$\begin{array}{c}\text { Mean } \\
\text { corpuscular } \\
\text { volume }\end{array}$} & \multicolumn{3}{|c|}{ Acids } & \multirow{2}{*}{$\begin{array}{l}\text { Polyunsaturated } \\
\text { fats }\end{array}$} & \multirow{2}{*}{$\begin{array}{c}\text { Monounsaturated } \\
\text { fats }\end{array}$} & \multirow{2}{*}{$\begin{array}{l}\text { Saturatec } \\
\text { fats }\end{array}$} \\
\hline & & & Palmitoleic & Oleic & Linoleic & & & \\
\hline $\begin{array}{l}\text { Alcohol } \\
\text { Log } \gamma-\text { glutamyltransferase activity* } \\
\text { Mean corpuscular volume } \\
\text { Palmitoleic acid } \\
\text { Oleic acid } \\
\text { Linoleic acid } \\
\text { Polyunsaturated fats } \\
\text { Monounsaturated fats }\end{array}$ & 0.352 & $\begin{array}{l}0.296 \\
0 \cdot 321\end{array}$ & $\begin{array}{l}0.397 \\
0.502 \\
0.407\end{array}$ & $\begin{array}{l}0.241 \\
0.245 \\
0.234 \\
0.558\end{array}$ & $\begin{array}{l}-0.286 \\
-0.312 \\
-0.237 \\
-0.675 \\
-0.751\end{array}$ & $\begin{array}{c}-0.020 \dagger \\
-0.019 \dagger \\
-0.019 \dagger \\
-0.104 \\
-0.203 \\
0.165\end{array}$ & $\begin{array}{r}0.102 \\
-0.014 \dagger \\
0.026 \dagger \\
0.014 \dagger \\
0.03 \dagger^{\dagger} \\
-0.020 \dagger \\
0.221\end{array}$ & $\begin{aligned} 0.060 \\
-0.058 \\
-0.033 \dagger \\
0.010 \dagger \\
0.034 \dagger \\
-0.049 \\
0.166 \\
0.751\end{aligned}$ \\
\hline
\end{tabular}


were measured as an index of lipid intake, ${ }^{17}$ and their distribution agreed with those recently reported..$^{18} 19$

The results emphasise the relation between consumption of alcohol and the relative proportion of palmitoleic, oleic, and linoleic acids in the plasma cholesterol esters of a group of healthy middle aged men. They agree with the finding of a higher proportion of monounsaturated fatty acids and a lower proportion of linoleic acid in human alcoholic fatty liver. ${ }^{4-7}$ The apparently stronger association of consumption of alcohol with palmitoleic acid than with the other cholesterol esters is consistent with the observation that the proportion of this fatty acid in adipose tissue best differentiates alcoholics from nonalcoholics. ${ }^{7}$ The association between consumption of alcohol and the pattern of fatty acids in cholesterol esters may reflect the stimulation of hepatic acid biosynthesis ${ }^{2320}$ or the change in 6-desaturase activity induced by alcohol ${ }^{21} 22$ rather than a different intake of fat in subjects drinking alcohol, as suggested by the results of the multiple regression analysis (table III).

The implications of these observations are twofold. Firstly, as palmitoleic acid appears to be an independent marker of consumption of alcohol it could be used in epidemiological or clinical studies together with other markers to compute a composite in lex of consumption even though its determination is rather tedious. Secondly, in studies in man consumption of alcohol should always be controlled when the relations between the fatty acids of serum cholesterol esters (and probably of other lipid components) and biological variables or conditions are investigated.

These results may help to improve understanding of the relation between the intake of lipids and alcohol and coronary heart disease, but this will depend on the effectiveness of the prospective information from this study.

We thank the Fondation Française de la Nutrition and the Haut Comité d'Etude et d'Information sur l'Alcoolisme for their financial support for this work.

\section{References}

1 Turchetto E, Ottani V, Zanetti P, Weiss $\mathrm{H}$. Hepatic fatty acids after ethanol ingestion. Nutritio et Dieta 1968;12:224-8.

2 Lieber CS, Spritz N, De Carli LM. Role of dietary, adipose and endogenously synthesized fatty acids in the pathogenesis of the alcoholic fatty liver. $\mathcal{F}$ Clin Invest 1966;45:51-62.

3 Scheig R, Isselbacker KJ. Pathogenesis of ethanol-induced fatty liver. III. In vivo and in vitro effects of ethanol on hepatic fatty acid metabolism in rat. F Lipid Res $1965 ; 6: 269-77$

Bertrand J L, Mallein R, Sabater P, Brette R. Etude chromatographique des lipides et des acides gras du foie dans les stéatoses hépatiques alcooliques.

5 Lieber CS, Spritz N. Effects of prolonged ethanol intake in man: role of dietary, adipose and endogenously synthesized fatty acids in the pathogenesis of the alcoholic fatty liver. $\mathcal{F}$ Clin Invest $1966 ; 45: 1400-11$.

6 Alling C, Aspenström G, Dencker SJ, Svennerholm L. Essential fatty acids in chronic alcoholism. Acta Med Scand [Suppl] 1979;631:1-38.

7 Berghaus G. Statistische Differenzierung zwischen Alcoholikern und Nichtalkoholikern anhand der Verfetting, des Fettsäuremusters und der Enzymaktivitäten der menschlichen Leber. $Z$ Rechtsmed 1978;82:113-20.

Yano K, Rhoads GG, Kagan A. Coffee, alcohol and risk of coronary heart disease among Japanese men living in Hawaii. $N$ Engl f Med 1977;297:405-9.

disease in Puerto Rico. Am $\mathcal{F}$ Epidemiol $1983 ; 117: 538-50$ and coronary heart

10 Shaper AG, Marr JW. Fatty acids and ischaemic heart-disease. Lancet 1978; $1146-7$.

11 Simpson HCR, Barker K, Caster RD, Cassels E, Mann JI. Low dietary intake of linoleic acid predisposes to myocardial infarction. Br Med $\mathcal{f} 1982 ; 285$ : 683-4.

12 Renaud S, Godsey F, Ortchanian E, Baudier F. Table de composition des aliments.

13 Persijn JP, Van Der Slik W. A new method for the determination of $\gamma$-glutamyl transferase in serum. F Clin Chem Clin Biochem 1976;14:421-7.

14 Folch J, Lees $M$, Sloane-Stanley $G H$. A simple method for the isolation and 15 Tuckey RC, Stevenson PM. Methanolysis of cholesteryl esters: conditions for quantitative preparation of methyl esters. Anal Biochem 1979;94:402-8.

$16 \mathrm{Papoz}$ L, Warnet JM, Péquignot G, et al. Alcohol consumption in a healthy population. Relationship to gamma-glutamyl-transferase activity and mean corpuscular volume. $7 A M A 1981 ; 245: 1748-51$.

17 Bernert JT Jr, Akins JR, Miller DT. Direct determination of the linoleate/oleate ratio in serum cholesterol esters by liquid chromatography. Clin Chem 1982;

18 Rocherbie RA, Dobson RD, Frohlich J. Gas-chromatographic analysis of patterns of fatty acids of cholesteryl esters and phosphatidylcholine. Clin Chem $1979 ; 25: 14114$.
Norbeck HE, Walldius G. Fatty acid composition of serum and adipose tissue lipids in males with chronic renal failure. Acta Med Scand 1982;211:75-85. Baraona E, Lieber CS. Effects of ethanol on lipid metabolism. $f$ Lipid Res 1979;20:289-315

21 Nervi AM, Peluffo RO, Brenner RR, Leikin AI. Effect of ethanol administration on fatty acid desaturation. Lipids 1980;15:263-8. Wang DL, Reitz RC. Ethanol ingestion and polyunsaturated fatty acids : effects

\title{
Clinical importance of the renin-angiotensin system in chronic heart failure: double blind comparison of captopril and prazosin
}

\author{
JOHN BAYLISS, MICHAEL S NORELL, RUDOLPH CANEPA-ANSON, COLIN REID, \\ PHILIP POOLE-WILSON, GEORGE SUTTON
}

\begin{abstract}
Nineteen patients with chronic heart failure participated in a double blind crossover trial of captopril and prazosin -two drugs with differing neuroendocrine effects-to determine whether neuroendocrine changes could ex-
\end{abstract}

Hillingdon Hospital, Uxbridge, Middlesex

JOHN BAYLISS, MRCP, registrar

MICHAEL S NORELL, MRCP, registrar

GEORGE SUTTON, MD, FRCP, consultant cardiologist

National Heart Hospital and Cardiothoracic Institute, London RUDOLPH CANEPA-ANSON, MRCP, senior registrar COLIN REID, MRCP, registrar

PHILIP POOLE-WILSON, MD, FRCP, professor of cardiology

Correspondence to: Dr G C Sutton, Hillingdon Hospital, Uxbridge, Middlesex. plain clinical and haemodynamic responses to treatment. Patients were assessed before and after acute and long term (four weeks') treatment with each drug given in random order. Sixteen patients completed the study.

During captopril haemodynamic improvement was maintained by inhibition of the renin-angiotensin system. Breathlessness was relieved in 15 patients and exercise capacity increased. During prazosin a reduction in systemic vascular resistance was maintained, but plasma renin activity and aldosterone and noradrenaline concentrations increased, fluid retention developed, and clinical benefit did not occur.

These results suggest that clinical and haemodynamic responses to long term vasodilator treatment for chronic heart failure are related to neuroendocrine changes. In patients with chronic heart failure inhibition of the renin-angiotensin system results in clinical benefit, whereas inhibition of the $\alpha$ adrenergic system does not. 